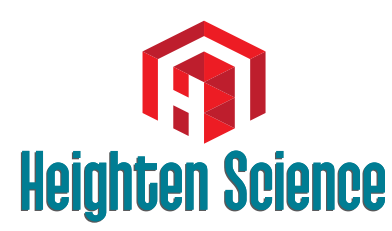

P U B L I C A T I O N S Corporation

\title{
Severe aorto-iliac occlusive disease: Options beyond standard aorto- bifemoral bypass
}

\author{
Konstantinos Filis*, Constantinos Zarmakoupis, Fragiska \\ Sigala and George Galyfos \\ Division of Vascular Surgery, 1st Department of Propedeutic Surgery, National and Kapodistrian \\ University of Athens Medical School, Hippocration Hospital, Athens, Greece
}

*Address for Correspondence: Konstantinos Filis, MD, PhD, Associate Professor of Vascular Surgery, Division of Vascular Surgery, 1st Department of Propedeutic Surgery, National and Kapodistrian University of Athens Medical School, Hippocration Hospital, 20 Aitolias Street, Athens, Greece, Tel: +30-6944681222; Fax: +302107707574; Email: kfilis@hotmail.com

Submitted: 17 December 2018

Approved: 26 December 2018

Published: 27 December 2018

Copyright: ๑ 2018 Filis K, et al. This is an open access article distributed under the Creative Commons Attribution License, which permits unrestricted use, distribution, and reproduction in any medium, provided the original work is properly cited

A) Check for updates
According to recent guidelines, endovascular angioplasty is the standard treatment for TASC A and B primary aorto-iliac occlusive (AIOD) disease, and the first-line approach for TASC C lesions [1,2]. Extended TASC D occlusive disease is usually treated by open surgery yielding excellent patency rates at a cost of a higher mortality (2\%-4\%) and a severe morbidity (up to 10\%) [3]. However, several studies have reported promising results after endovascular treatment of extensive AIOD and full reconstruction of the aortic bifurcation [4,5]. In a recent meta-analysis, Jongkind et al., concluded that endovascular treatment of extensive AIOD can be performed successfully by experienced interventionists in selected patients [6]. Although primary patency rates seem to be lower than those reported for surgical revascularization, reinterventions can often be performed percutaneously yielding a secondary patency comparable to surgical repair.

Common causes of chronic infrarenal aortic occlusion (CIAO) include: i) atherosclerotic occlusive disease; ii) middle aortic syndrome; iii) Takayasu arteritis; iv) fibromuscular dysplasia; v) neurofibromatosis; and vi) coral reef aorta [3,79]. Although standardized infrarenal aorto-bifemoral bypass (AoBFB) remains the surgical procedure of choice for CIAO, operative decisions may proceed beyond AoBFB in complicated cases. Different therapeutic strategies include axillo-(bi)femoral bypass (AxBFB), aortoiliac endarterectomy (AIE) or hybrid procedures. AxBFB grafting usually refers to patients of high risk for aortic clamping or patients with many comorbidities that prohibit an extensive transperitoneal procedure [10]. However, its primary patency is usually inferior compared to classic aortofemoral bypass surgery and $\mathrm{AxBFB}$ is associated with an increased risk for infections. In a recent systematic review, anatomical open procedures such as AIE showed very low perioperative mortality, with 5-year primary patency rates of over 80\% [11]. Finally, hybrid procedures show equivalent midterm primary patency rates with the open procedures even for TASC D lesions while reducing perioperative mortality rates [12]. Hybrid procedures for aortoiliac disease usually include iliac stenting plus femoral endarterectomy or femorofemoral bypass.

Regarding our experience, operative decisions in a series of 58 consecutive patients with CIAO treated in our division, were based on: a) anatomic extension of the disease as presented in digital subtraction angiography (DSA), b) pattern and grade of calcification as presented in non-contrast computed tomography (CT) scan, c) grade of claudication and d) patients' medical status to assess the risk/ benefit ratio. A careful evaluation using proper imaging modalities plays a very essential role 
in decision making. Ultrasonography may still be the first approach for patients with AIOD, although further angiography is important for evaluating collateral pathways and planning any intervention [13,14]. Traditional DSA was formerly the golden standard for illustrating the entire aortoiliac tree although due to its invasiveness, it is now preferred when a concurrent endovascular treatment is scheduled [15]. Modern CT angiography and magnetic resonance angiography (MRA) are less invasive studies and they show an equivalent performance in illustrating the entire aortoiliac tree in detail, the extent of the calcifications and collateral pathways [16-18]. Therefore, they are preferred as first-line diagnostic tools compared to DSA.

In our series, patency of at least $2 \mathrm{~cm}$ below the level of the lowest renal artery was considered sufficient for a standard AoBFB. However, juxtarenal occlusion was managed with thrombo-endarterectomy of the proximal infrarenal aorta and AoBFB, during either infrarenal (after endarterectomy) or suprarenal (before endarterectomy) clamping. Infrarenal aortic clamping is not feasible in cases with circumferential aortic calcification and calcium thickness more than $2 \mathrm{~mm}$ on CT scan (coral reef aorta). Regarding clinical presentation, claudication distance of more than $100 \mathrm{~m}$ and/or AnkleBrachial Index $(\mathrm{ABI})>0.7$ were considered relative indications for surgery, whereas claudication of less than $100 \mathrm{~m}$ and/or $\mathrm{ABI}<0.7$ were considered strong indications for surgery. Operative risk assessment was considered based on cardiac, pulmonary and renal disease, using objective criteria $[19,20]$. Age and patient's preference were also taken into consideration. Imaging, clinical presentation and surgical procedures performed in six consecutive patients from our series are presented in table 1 . Outcomes are also presented in table 1.

Coral reef aorta, which is a rare entity of extensive aorta calcification characterized by the unique consistency of lesions which are rock-hard, was an absolute contraindication for AoBFB in our series (Figures 1-3). Therefore, in cases of higher surgical risk, AxBFB was selected in order to decrease perioperative morbidity although supraceliac AoBFB was selected in cases of juxtarenal occlusion and a lower surgical risk. Several authors have reported optimal results with aortic bypass following aortorenal thrombectomy under suprarenal aortic clamping or transient aortic compression for patients with juxtarenal occlusion [21,22]. However, when the aorta is fully calcified - such as in our cases, clamping in the proximity of the renal arteries is forbidding and supraceliac anastomosis may be an alternative in case of standard risk.

Furthermore, we have recently reported a hybrid technique for treating aortic aneurysms with a coral reef aorta as well [23]. Proximal endovascular occlusion of

Table 1: Anatomic and physiologic factors of patients with CIAO not amenable to standard aorto-bifemoral bypass (AoBFB). (DSA, digital subtraction angiography; $C T$, computed tomography; $A B I$, Ankle-Brachial Index; $R$, right; $L$, left)

\begin{tabular}{|c|c|c|c|c|c|c|}
\hline Patients & Surgery & Dsa & $\begin{array}{c}\text { Ct } \\
\text { Calcium }\end{array}$ & $\begin{array}{c}\text { Claudication/ } \\
\text { Abis }\end{array}$ & $\begin{array}{l}\text { Surgical } \\
\text { Risk }\end{array}$ & Early Outcomes \\
\hline Patient 1 & $\begin{array}{c}\text { Aortic } \\
\text { endarterectomy and } \\
\text { AoBFB }\end{array}$ & $\begin{array}{l}\text { Juxtarenal } \\
\text { occlusion }\end{array}$ & Sporadic & $\begin{array}{l}\text { Severe/ } \\
\text { R:0.6 } \\
\text { L:0.7 }\end{array}$ & Standard & $\begin{array}{c}\text { Reversible renal } \\
\text { dysfunction, troponin } \\
\text { elevation }\end{array}$ \\
\hline Patient 2 & Supraceliac AoBFB & $\begin{array}{c}\text { Occlusion } 3 \mathrm{~cm} \\
\text { below lower renal } \\
\text { artery }\end{array}$ & Coral reef & $\begin{array}{c}\text { Severe/ } \\
\text { R:0.7 } \\
\text { L:0.7 }\end{array}$ & Standard & Atrial fibrillation \\
\hline Patient 3 & $\begin{array}{c}\text { Axillary- bifemoral } \\
\text { bypass }\end{array}$ & $\begin{array}{l}\text { Juxtarenal } \\
\text { occlusion }\end{array}$ & Coral reef & $\begin{array}{c}\text { Severe/ } \\
\text { R: No signal } \\
\text { L:0.5 }\end{array}$ & High & Pulmonary infection \\
\hline Patient 4 & Supraceliac AoBFB & $\begin{array}{l}\text { Juxtarenal } \\
\text { occlusion }\end{array}$ & Coral reef & $\begin{array}{c}\text { Severe/ } \\
\text { R:0.5 } \\
\text { L:0.7 }\end{array}$ & Standard & $\begin{array}{l}\text { Reversible renal } \\
\text { dysfunction }\end{array}$ \\
\hline Patient 5 & $\begin{array}{c}\text { Axillary- bifemoral } \\
\text { bypass }\end{array}$ & $\begin{array}{l}\text { Juxtarenal } \\
\text { occlusion }\end{array}$ & Sporadic & $\begin{array}{l}\text { Mild/ } \\
\text { R:0.8 } \\
\text { L:0.7 }\end{array}$ & High & Troponin elevation \\
\hline Patient 6 & $\begin{array}{c}\text { Axillary- bifemoral } \\
\text { bypass }\end{array}$ & $\begin{array}{c}\text { Occlusion } 3 \mathrm{~cm} \\
\text { below lower renal } \\
\text { artery }\end{array}$ & Coral reef & $\begin{array}{l}\text { Severe/ } \\
\text { R:0.6 } \\
\text { L:0.6 }\end{array}$ & High & $\begin{array}{l}\text { Femoral wound } \\
\text { healing delay }\end{array}$ \\
\hline
\end{tabular}




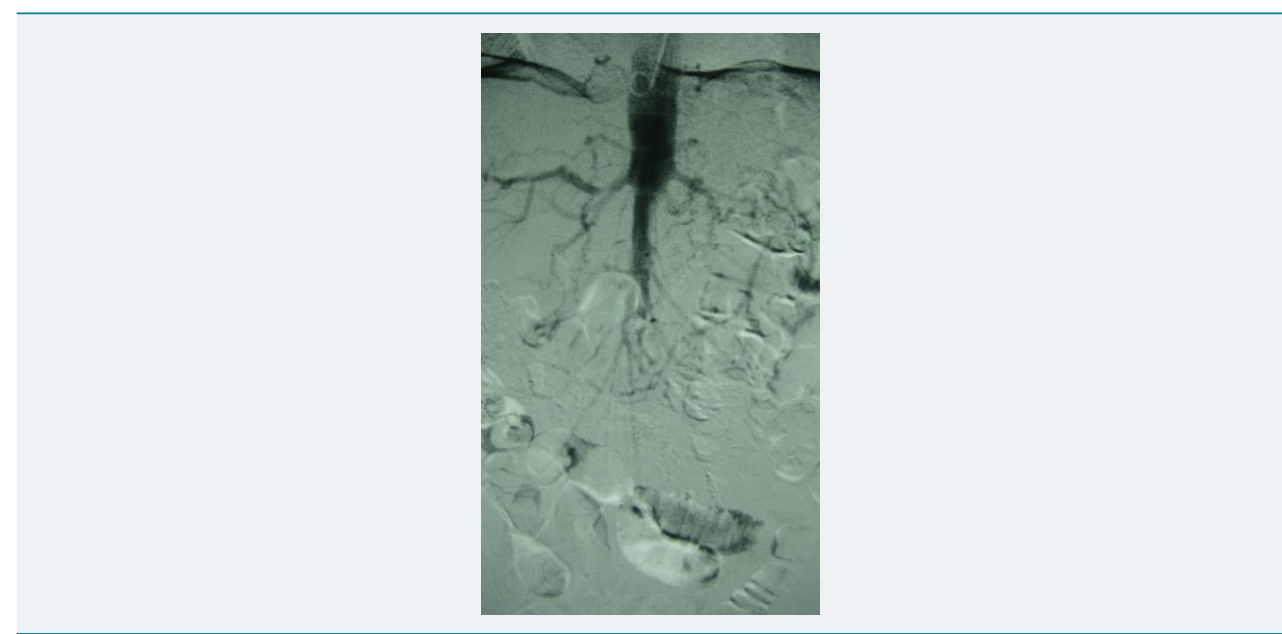

Figure 1: A digital subtraction angiography (DSA) image shows a short infrarenal segment of the abdominal aorta with limited patency.

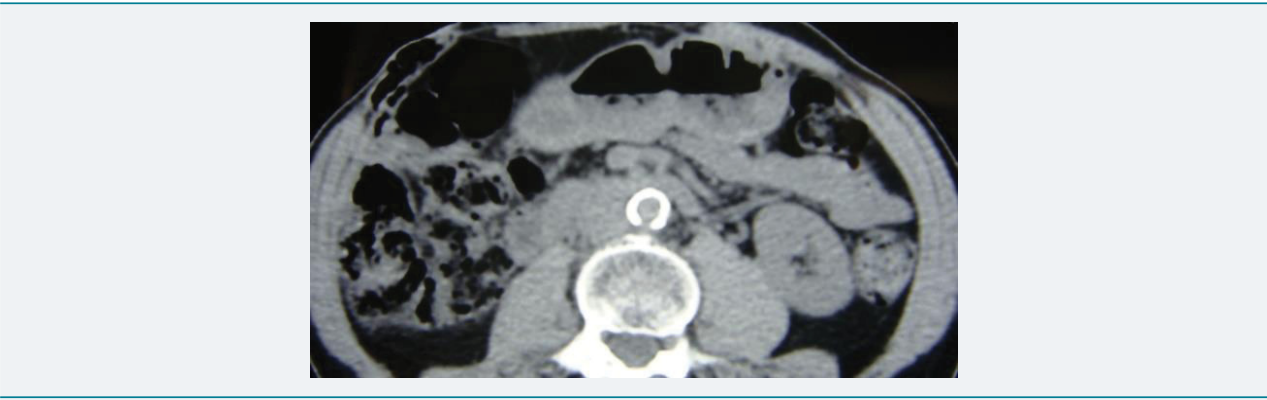

Figure 2: Non-contrast computed tomography showing a coral reef infrarenal aorta.

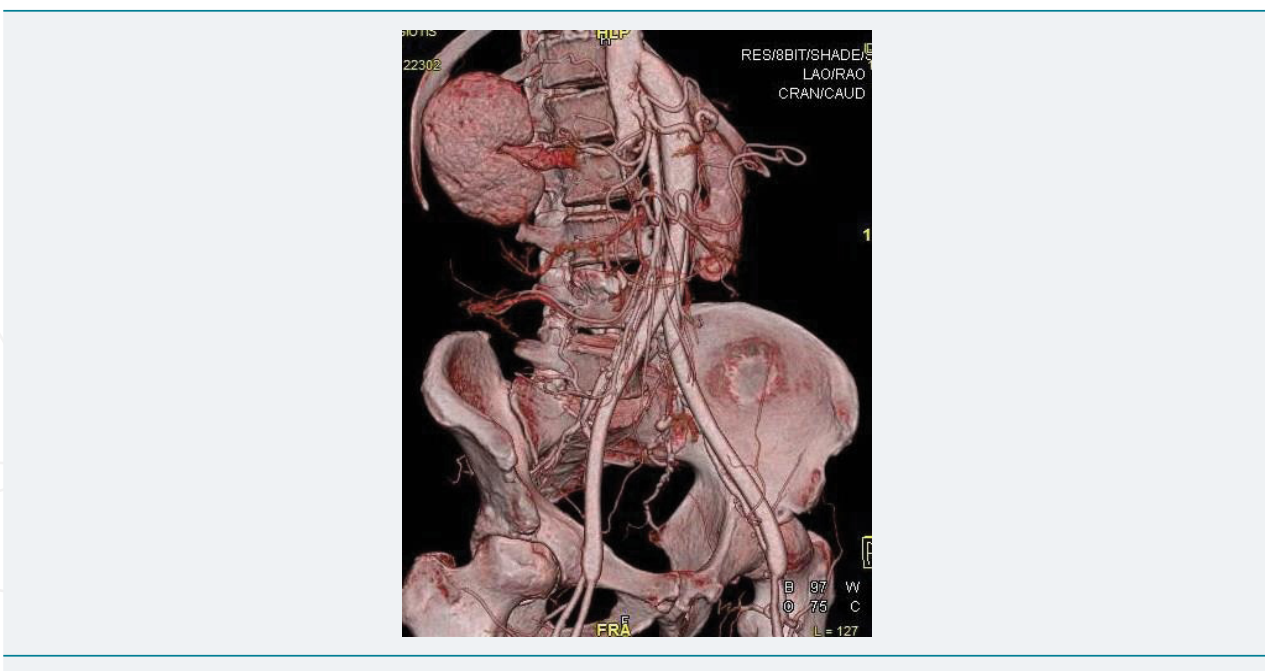

Figure 3: A 3D-computed tomography angiography (CTA) image shows a patent supraceliac aorto -bifemoral bypass.

the aorta, careful mobilizations, aortic wall drilling, and tight suturing of the graft yielded a satisfying result. Other techniques including clampless and sutureless aortic anastomosis have been described for patients with extensive aortic calcifications [24]. Hybrid or endovascular techniques are usually associated with lower perioperative mortality, especially in patients of high surgical risk although they could cause various complications. Cerebral infarction, peripheral embolism, access site complications and target lesion revascularization are more frequent in institutions with a low experience in endovascular procedures and especially in patients with TASC D lesions [25,26]. Therefore, treatment should be always individualized and performed in experienced vascular centers. 
Finally, evidence based decisions towards best treatment of severe CIAO, when standard AoBFB is not feasible, are lacking. Although, major aortic surgery carries a considerable operative risk, we have shown that modern anesthetic and perioperative treatment strategies in abdominal aortic surgery result in decreased postoperative pain, decreased intensive care unit and in-hospital stay, and therefore, decreased morbidity and mortality, even patients with severe pulmonary disease [27]. Furthermore, proper antithrombotic coverage, early initiation of beta-blockage and statin treatment has been associated with improved outcomes in such patients [28-30]. However, there are cases suggesting excellent long-term outcomes by non operative treatment in patients with juxtarenal occlusion and mild claudication [31], and therefore, open surgery for CIAO warrants extremely prudent risk/benefit assessment.

\section{References}

1. Wressnegger $A$, Kinstner $C$, Funovics $M$. Treatment of the aorto-iliac segment in complex lower extremity arterial occlusive disease. J Cardiovasc Surg (Torino). 2015; 56: 73-79. Ref.: https://goo.gl/77uqTK

2. Aggarwal V, Waldo SW, Armstrong EJ. Endovascular revascularization for aortoiliac atherosclerotic disease. Vasc Health Risk Manag. 2016; 12: 117-127. Ref.: https://goo.gl/Eb9Fvr

3. Indes JE, Pfaff MJ, Farrokhyar F, Brown H, Hashim P, et al. Clinical outcomes of 5358 patients undergoing direct open bypass or endovascular treatment for aortoiliac occlusive disease: a systematic review and meta-analysis. J Endovasc Ther. 2013; 20: 443-455. Ref.: https://goo.gl/qYWV1N

4. Krankenberg $\mathrm{H}$, Schlüter $\mathrm{M}$, Schwencke $\mathrm{C}$, Walter $\mathrm{D}$, Pascotto $\mathrm{A}$, et al. Endovascular reconstruction of the aortic bifurcation in patients with Leriche syndrome. Clin Res Cardiol. 2009; 98: 657-664. Ref.: https://goo.gl/9TDU6u

5. Mangialardi N, Ronchey S, Serrao E, Fazzini S, Alberti V, et al. Endovascular management of total juxtarenal aortic occlusive disease in high-risk patients: technical considerations and clinical outcome. J Cardiovasc Surg (Torino). 2017; 58: 422-430. Ref.: https://goo.gl/SRk6j3

6. Jongkind V, Akkersdijk GJ, Yeung KK, Wisselink W. A systematic review of endovascular treatment of extensive aortoiliac occlusive disease. J Vasc Surg. 2010; 52: 1376-1383. Ref.: https://goo.gl/eJ37NF

7. Verma H, Baliga K, George RK, Tripathi RK. Surgical and endovascular treatment of occlusive aortic syndromes. J Cardiovasc Surg (Torino). 2013; 54(1 Suppl 1): 55-69. Ref.: https://goo.gl/nmCpHc

8. Kim SM, Jung IM, Han A, Min SI, Lee T, et al. Surgical treatment of middle aortic syndrome with Takayasu arteritis or midaortic dysplastic syndrome. Eur J Vasc Endovasc Surg. 2015; 50: 206-212. Ref.: https://goo.gl/uCKLHh

9. Pranteda C, Menna D, Capoccia L, Sirignano P, Mansour W, et al. Simultaneous Open Surgical Treatment of Aortic Coral Reef and Leriche Syndrome: Case Report and Literature Review. Ann Vasc Surg. 2016; 32: 133. e1-5. Ref.: https://goo.gl/ea8892

10. Illuminati G, Calio FG, Mangialardi N, Bertagni A, Vietri F, et al. Results of axillofemoral by-passes for aorto-iliac occlusive disease. Langenbecks Arch Chir. 1996; 381: 212-217. Ref.: https://goo.gl/fk2ECG

11. Chiu KW, Davies RS, Nightingale PG, Bradbury AW, Adam DJ. Review of direct anatomical open surgical management of atherosclerotic aorto-iliac occlusive disease. Eur $\mathrm{J}$ Vasc Endovasc Surg. 2010; 39: 460-471. Ref.: https://goo.gl/QM4txW

12. Chen TW, Huang CY, Chen PL, Lee CY, Shih CC, et al. Endovascular and Hybrid Revascularization for Complicated Aorto-lliac Occlusive Disease: Short-Term Results in Single Institute Experience. Acta Cardiol Sin. 2018; 34: 313-320. Ref.: https://goo.gl/1dHHAa

13. Styczynski G, Szmigielski C, Leszczynski J, Kuch-Wocial A, Szulc M. Abdominal aortic Doppler waveform in patients with aorto-iliac disease. Eur J Vasc Endovasc Surg. 2010; 39: 714-718. Ref.: https://goo.gl/vwp2ih

14. Lowery AJ, Hynes N, Manning BJ, Mahendran M, Tawfik S, et al. A prospective feasibility study of duplex ultrasound arterial mapping, digital-subtraction angiography, and magnetic resonance angiography in management of critical lower limb ischemia by endovascular revascularization. Ann Vasc Surg. 2007; 21: 443-451. Ref.: https://goo.gl/Qo79FA

15. Rosen RJ, Roven SJ, Taylor RF, Imparato AM, Riles TS. Evaluation of aorto-iliac occlusive disease by intravenous digital subtraction angiography. Radiology. 1983; 148: 7-8. Ref.: https://goo.gl/dZ1Wbg

16. Mesurolle B, Qanadli SD, El Hajjam M, Goeau-Brissonnière OA, Mignon F, et al. Occlusive arterial disease of abdominal aorta and lower extremities: comparison of helical CT angiography with transcatheter angiography. Clin Imaging. 2004; 28: 252-260. Ref.: https://goo.gl/h9VXbn 
17. Krug B, Kugel H, Harnischmacher U, Heindel W, Fischbach R, et al. Diagnostic performance of digital subtraction angiography (DSA) and magnetic resonance angiography (MRA): preliminary results in vascular occlusive disease of the abdominal and lower-extremity arteries. Eur J Radiol. 1995; 19: 77-85. Ref.: https://goo.gl/HgWUSK

18. Akinwande $\mathrm{O}$, Ahmad A, Ahmad S, Coldwell D. Review of pelvic collateral pathways in aortoiliac occlusive disease: demonstration by CT angiography. Acta Radiol. 2015; 56: 419-427. Ref.: https://goo.gl/2KqXCT

19. Galyfos $\mathrm{G}$, Filis $\mathrm{K}$. Is the revised cardiac risk index the right risk index for vascular surgery patients? Crit Care Med. 2014; 42: e631-632. Ref.: https://goo.gl/LyUrp2

20. Van Damme H, Piérard L, Gillain D, Benoit T, Rigo P, et al. Cardiac risk assessment before vascular surgery: a prospective study comparing clinical evaluation, dobutamine stress echocardiography, and dobutamine Tc-99m sestamibi tomoscintigraphy. Cardiovasc Surg. 1997; 5: 54-64. Ref.: https://goo.gl/gEi1bG

21. Jun HJ. Experiences of Surgical Treatment for Juxtarenal Aortic Occlusion. Vasc Specialist Int 2014; 30: 19-25. Ref.: https://goo.gl/QH9neu

22. Yang SS, Kim YW, Park YJ, Kim DI, Woo SY, et al. Results of Open Surgical Repair of Chronic Juxtarenal Aortic Occlusion. Vasc Specialist Int. 2014; 30: 81-86. Ref.: https://goo.gl/tq9Wr5

23. Galyfos G, Sigala F, Basigos G, Karantzikos G, Katsaragakis S, et al. Hybrid Treatment of an Abdominal Aortic Aneurysm with Severe Calcification of the Neck and Aortic Bifurcation. Ann Vasc Surg. 2016; 36: 294.e7-294.e11. Ref.: https://goo.gl/MPoczn

24. Papadimitriou D, Mayer D, Lachat M, Pecoraro F, Frauenfelder $T$, et al. A clampless and sutureless aortic anastomosis technique using an endograft connector for aortoiliac occlusive disease in which the aorta cannot be clamped or sewn due to calcification or scarring. Vascular. 2012; 20: 262-267. Ref.: https://goo.gl/iCvUoD

25. Suzuki K, Mizutani Y, Soga Y, lida O, Kawasaki D, et al. Efficacy and Safety of Endovascular Therapy for Aortoiliac TASC D Lesions. Angiology. 2017; 68: 67-73. Ref.: https://goo.gl/kR8GXH

26. Sixt $S$, Krankenberg $H$, Möhrle $C$, Kaspar $M$, Tübler $T$, et al. Endovascular treatment for extensive aortoiliac artery reconstruction: a single-center experience based on 1712 interventions. J Endovasc Ther. 2013; 20: 64-73. Ref.: https://goo.gl/cs7dwv

27. Panaretou V, Toufektzian L, Siafaka I, Kouroukli I, Sigala F, et al. Postoperative pulmonary function after abdominal aortic aneurysm repair in patients with chronic obstructive pulmonary disease: epidural versus intravenous analgesia. Ann Vasc Surg. 2012; 26: 149-155. Ref.: https://goo.gl/NnqiBU

28. Galyfos G, Sianou A, Filis K. Pleiotropic effects of statins in the perioperative setting. Ann Card Anaesth. 2017; 20(Supplement): S43-S48. Ref.: https://goo.gl/zzu1Gd

29. Galyfos G, Filis K, Sigala F, Geropapas G. Beta-blockers in vascular surgery patients: is the debate still going on? J Anesth. 2016; 30:1031-1036. Ref.: https://goo.gl/yV6ovp

30. Filis K, Tsioufis C, Sianou A, Triantafillou K, Sigala F, et al. Critical evaluation on proper antithrombotic treatment in different groups of patients undergoing vascular surgery. Hellenic J Cardiol. 201830. pii: S1109-9666(18)30071-X. Ref.: https://goo.gl/NuvapQ

31. San Norberto, E, Carrera S, Tyalor J, Vaquero C. Thirty years with a chronic aortic occlusion. J Vasc Surg 2013; 57: 1128. Ref.: https://goo.gl/VpH25T 